\title{
Land use and Land Cover Change Analysis, Causes and Effects on Agricultural Productivity, Case of Anlemo District in Hadiya zone, Ethiopia
}

\author{
Yohannes Horamo $^{1}{ }^{*}$, Fekadu Ayele ${ }^{2}$, Habtewold Atiso ${ }^{3}$ \\ ${ }^{1 *}$ Department of Natural Resources Management Wachemo University, Ethiopia \\ ${ }^{2}$ Department of Natural Resources Management Wachemo University, Ethiopia \\ ${ }^{3}$ Department of Natural Resources Management Wachemo University, Ethiopia \\ *Corresponding Author Email: yohannesh2005@gmail.com
}

Received: 3.12.2021; Revised: 28.12.2021; Accepted: 29.12.2021

OSociety for Himalayan Action Research and Development

\begin{abstract}
Change in land use land cover (LULC) is one of the constraints which can influence the development of sustainable agricultural in the study area. The change in LULC can negatively affect the possible use of land and completely lead to soil and vegetation degradation that have an influences on crop productivity. LULC change analysis was conducted in Anlemo District in Hadiya zone, Ethiopia for the period of 2000-2018, using Remote Sensing satellite image and Geographic Information System with field verifications. This was to look at LULC change, its causes and influences on crop productivity in Anlemo District. In this study, LULC maps of 2000, 2010 and 2018, and change maps of 2000-2010 and 20102018 were produced. Results from LULC change analysis revealed an increase in agricultural land from $36.6 \%$ in 2000 to $55.764 \%$ in 2018 . The increase of agricultural land was mainly at the cost of vegetation and grazing land cover change. Vegetation cover decreased from $21.81 \%$ in 2000 to $14.601 \%$ in 2018 . Shrub land area was $38.81 \%$ in 2000 that decreased to $19.933 \%$ in 2018 and wetland which was $0.817 \%$ in 2000 increased to $1.057 \%$ in 2018 . The study also made known that the main reasons of LULC changes were mainly, expansion of agricultural land and clearing vegetation. Therefore, these urges to initiate mechanized farming system that permits small land holder farmers to obtain more crop products from their small plot of land and to use alternative sources for fuel to reduce the complete reliance of rural community on forest products.
\end{abstract}

Keywords: LULC change, GIS, vegetation, crop productivity

\section{Introduction}

Background and Justification: Globally land use and land cover change today is altered principally by direct human use, by agriculture and livestock rising, forest clearing and mismanagement and urban and suburban construction and development (Shiferaw, Singh 2011, Baude et al 2017). A serious problem the world is facing at present is the deterioration of both the natural environment and natural resources. Human activities generate environmental pressure in different ways. Among them is overexploitation of renewable resources such as forests, and degradation of basic resources such as land and water (Gessesse 
et al 2015, Alemu 2015). The awareness about the importance of land use and land cover change (LULC) study among global issues has risen for its nexus on global human security and quality of the environment. Furthermore, LULC change is a critical issue due to its great influence on land degradation, biodiversity loss, water quality, effects, and human life. Analyzing the land cover changes and understanding the subsequent trends of change contribute to present complex dynamics of LULC and are important for planning and policy making and sustainable management of resources (Firdaus 2014, Wessels 2016). Land use and cover changes could lead to a decreased availability of different products and services for human, livestock, agricultural production and damage to the environment as well (Islam et al 2002).

In Ethiopia, the causes of land cover change particularly natural forest destruction were agricultural expansion, both through shifting cultivation and the spread of sedentary agriculture; the demand for increasing amounts of construction material, fuel wood and charcoal (Kahsay 2018). According to Ejigu (2016), the main causes of land use land cover change and fertility decline in the study area are deforestation, removal of crop residues from fields, land fragmentation, reduction of fallowing periods, overgrazing, low fertilizer inputs, inadequate soil and water conservation practices and cropping of marginal lands. These have resulted in lowering of agricultural production, leading to food insecurity and increased poverty.

Anlemo District is part of Hadiya zone which is exposed to high land degradation as per the previous observation of the researcher in many ways. The reasons for land use and land cover change drivers and its impact on agricultural productivity in the study area may include rapid population growth, resettlement and land shortage which forced farming families to increase their agricultural fields in to shrub and/or natural vegetation. In addition, local vegetation cover changed by biophysical and socio-economic drivers, especially vegetation cover change by animal feed/grazing, construction materials and charcoal production/fuel wood has significant and cumulative impact on the study area. These factors also would cause seasonal flooding of farmlands in the bottomlands, which might affect several farming families and agricultural productivity. Furthermore, rising and falling topography which makes it vulnerable for soil fertility decline, deforestation and causing soil erosion. However, none of these situations of the study area have been systematically investigated by previous studies.

Therefore, this study aims to analyze land use and land cover changes, Causes and effects on agricultural productivity in Anlemo District from 2000 to 2018. As well having the research questions (1) What are the major cause of land use and land cover change in the study area? (2) What are the fundamental 
services behind forest and other land use and land cover change? (3) How does land use and land cover change affect agricultural productivity in Anlemo District?

\section{METHODOLOGY}

Description of the Study Area : The study was conducted in Anlemo District, Hadiya zone, Ethiopia.

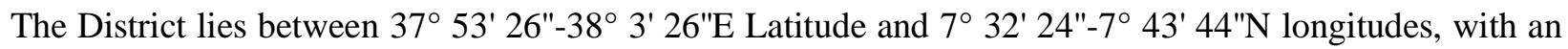
elevation ranging from 2200-2600 meters above sea level. Regarding the Agro-ecology, $21.5 \%$ is "Dega", $57 \%$ is "Woina Dega" and $21.5 \%$ is "Kolla". The annual temperature shows that $25^{\circ} \mathrm{C}$ annual mean maximum temperature. Mean minimum annual temperature is $23^{\circ} \mathrm{C}$. Also the District experiences medium temperature or the climate in the District is mild tropical type. The rainfall was a bimodal type, the short rainy season was between (February to March) and the long between (June to September). The average annual rainfall ranges from $1001 \mathrm{~mm}$ to $1200 \mathrm{~mm}$.

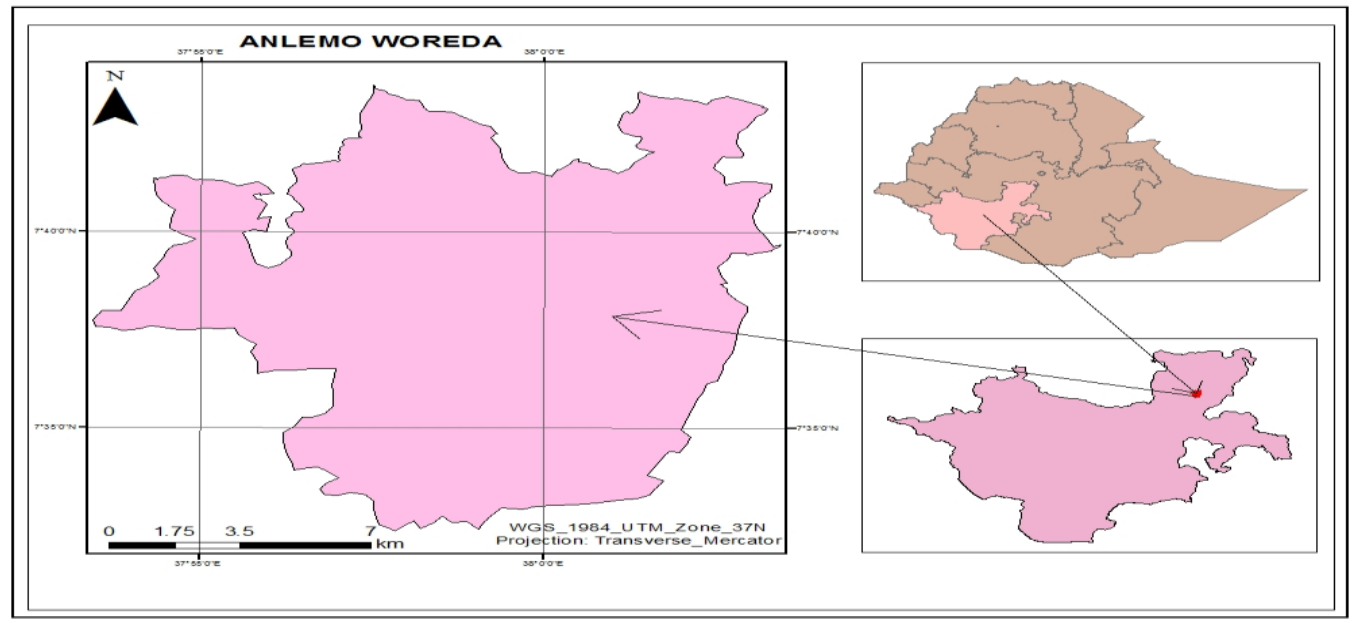

Figure 1: Location of Anlemo District in Hadiya Zone, Ethiopia

Types and Sources of Data : A satellite images was the main source of spatial data for the study. Landsat with path and row 169 and 055 respectively and spatial resolution of 30mx30m were obtained from Global Land Cover Facilities (GLCF) and United States Geological Survey (USGS). The three satellite images were acquired in the same season. The satellite images were used to evaluate land cover and land use changes of the past twenty eight years. Tools of data collection for spatial one were by using internet and Global Positioning System.

The primary sources of socio-economic data were through questionnaires, interview and observation. Secondary sources of data were collected from published and unpublished materials such as office records and reports, journals and articles, books; data was also be collected from Agricultural office of Anlemo (study District), Ethiopia Meteorological Agency (EMA). Socio economic data was collected by using direct field observation, Digital Camera, Key Informant Interview, structured and open-ended 
questionnaire were used to gather information about the process and reasons of land use and land cover changes, its causes and effects on crop productivity in the past and present.

Sample Size Determination : Two stage (multi-stage) sampling methods were employed to select sample from population. First, 3 kebeles were selected purposively out of the 28 kebeles existing in Anlemo District: secondly, sample households were selected from each sample kebele by using random sampling method from list of kebeles households. The simplified formula of (Yamane 1967) was used to determine sample sizes. The formula assumes a 95\% confidence level and the maximum variance $(\mathrm{p}=$ $0.05)$ :

$$
\mathrm{n}=\frac{\mathrm{N}}{1+\mathrm{N}(\mathrm{e})^{2}}
$$

Where: $\mathrm{n}$-is the sample size, $\mathrm{N}$-is the population size, e -specifies the desired level of precision, where e $=1-$ precision $(0.05$ limit of tolerable error $)$ level of precision $=95 \%(0.091=$ a theoretical or statistical constant). By applying the above formula, sample household heads was selected from the 3 kebeles. Additionally, 3 groups of key informants (1 from each kebele) consists of 8 members were purposively selected. Prior to the beginning of the actual survey and interview processes, consent was presented of each respondent to request their willingness to participate in the final interview.

Data Analysis : Spatial data analysis was performed to get important information from the acquired landsat TM and ETM+ satellite image of the years 2000, 2010 and 2018. In order to generate images ENVI 4.7 was used at different stages. Land use and land cover classification accuracy were assessed in order to examine whether the classification result reflects the reality on the ground. The classified images were exported to ArcGIS 10.5 and land use and land cover maps of the year 2000, 2010 and 2018 were produced. Analyses of socio-economic data were done after checking completeness of quantitative data, descriptive measures like frequency and percent were generated.

\section{RESULTS AND DISCUSSION}

Land Use Land Cover Change Analysis : For the purpose of land use land cover change analysis the techniques used were ArsGIS10.5 software, Land use and land cover classification for 2000 from TM satellite image in (Figure 3) showed that majority of the study area was under crop land/ agricultural land accounts $(36.6 \%)$ but settlements and wetland coverage amounted to be about $(3.83 \%)$ and $(0.96 \%)$ respectively in agreement with (Kindu et al 213). The land use land cover classification for 2009 from ETM+ satellite image in the (Figure 4) showed that crop land/agricultural land cover accounting for $(46.95 \%)$. 
This showed that crop land/agricultural land increased from $36.6 \%$ in 2000 to $46.95 \%$ in the year 2009 . The land use and land cover classification for 2018 from Landsat 8 satellite image on (Figure 5) showed that crop land/agricultural land cover is dominant class while, vegetation cover was decreasing that is in harmony with that of (Mussa et al 2017, Sewnet 2016). The identified details through assessment of land use land cover were summarized in the following (Figures 02-08).

According to satellite image classification in more than half of land use and land cover classification covered by crop land/agricultural land compare to other classes. In the year 2000 to 2018, most portion of the land use land cover class was agricultural land. The increment of agricultural land and built up area was because of large number of population pressure in the study District. In the (Figures 3, 4 \& 5) and Table 1, 2, 3, 4, 5 \& 6) Land use land cove types in different years which is in agreement with the study of (Abate and Lemenih 2014, Kidane et al 2012). Most portion of the land use land cover class was agricultural land during this period. Generally, agricultural land and built up area also shows increment through 2000 to 2018 indicates population pressure in the district. But forest cover shows continuous decrease in the above time interval which the same idea has been reported by Firdaus et al (2014).
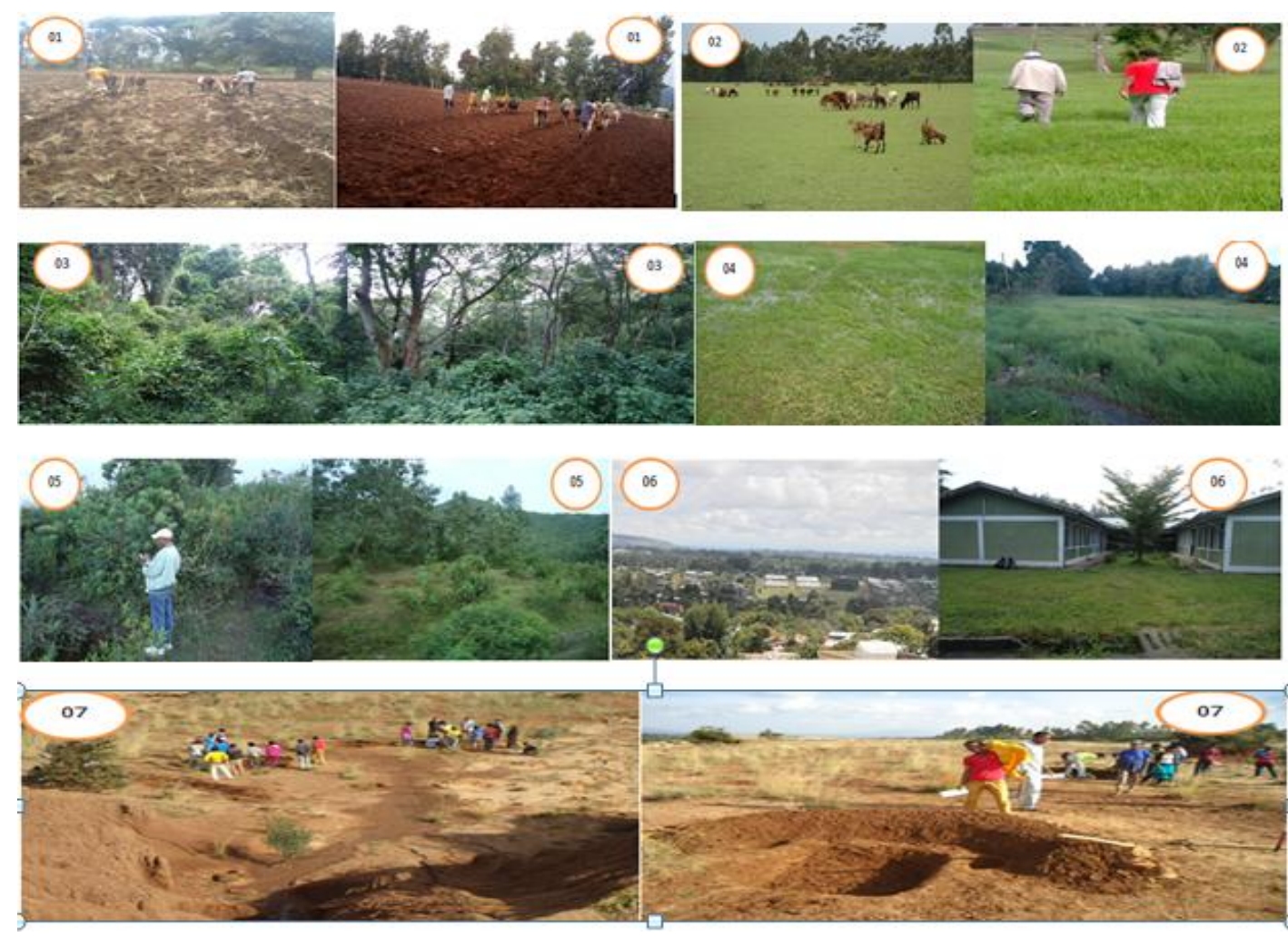

01 Crop land, 02 Grass land, 03 Forest land, 04 Wetland, 05 Bush land, 06 Settlements (Built up), 07 Bare land 
Himalayan J. Soc. Sci. \& Humanities ISSN: 0975-9891

Vol. 16, (2021) 13-33

DOI: https://doi.org/10.51220/hjssh.v16i1.2

Table 1: Land use land cover change of 2000 to 2009 in hectares

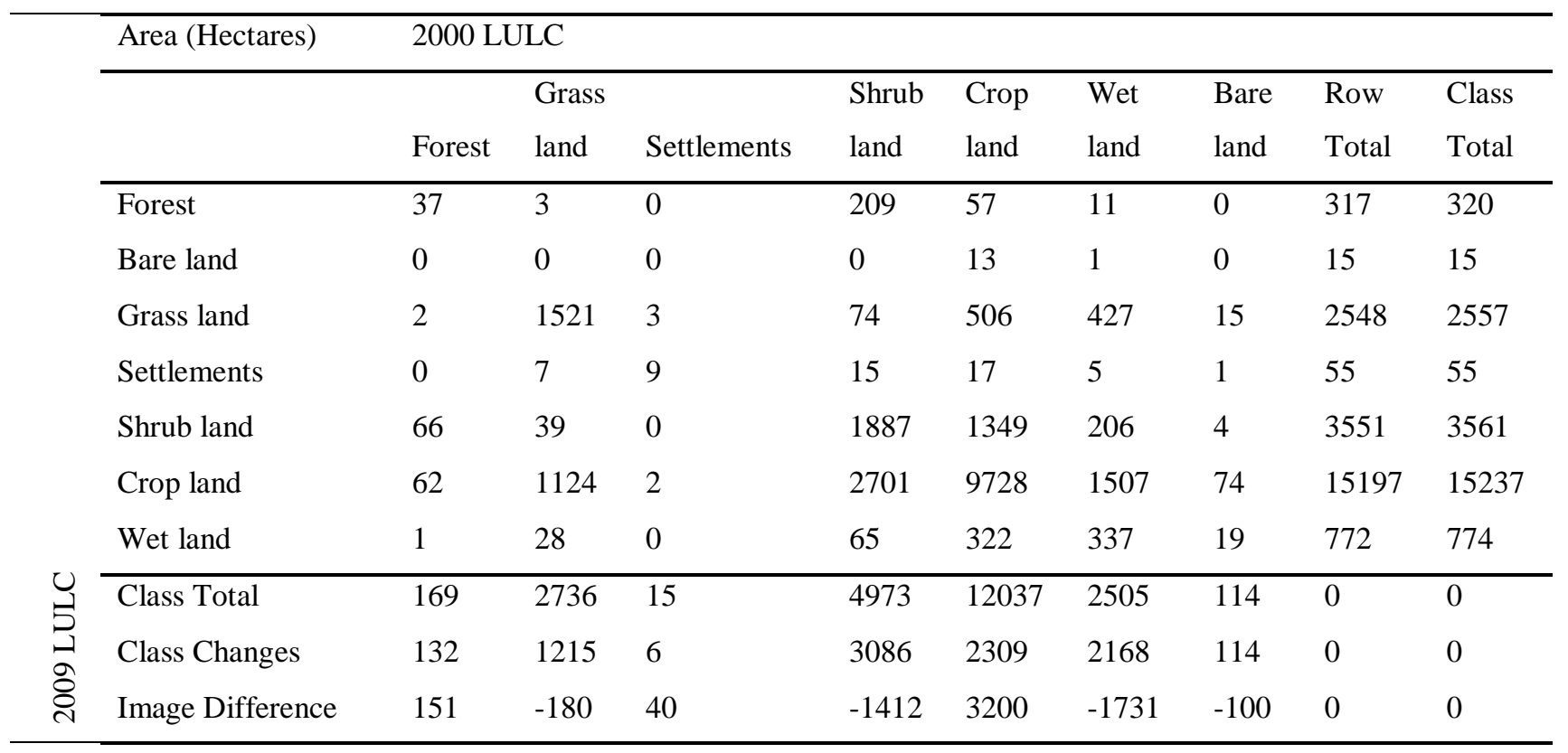

Table 2: Land use land cover change of 2000 to 2009 in percentages

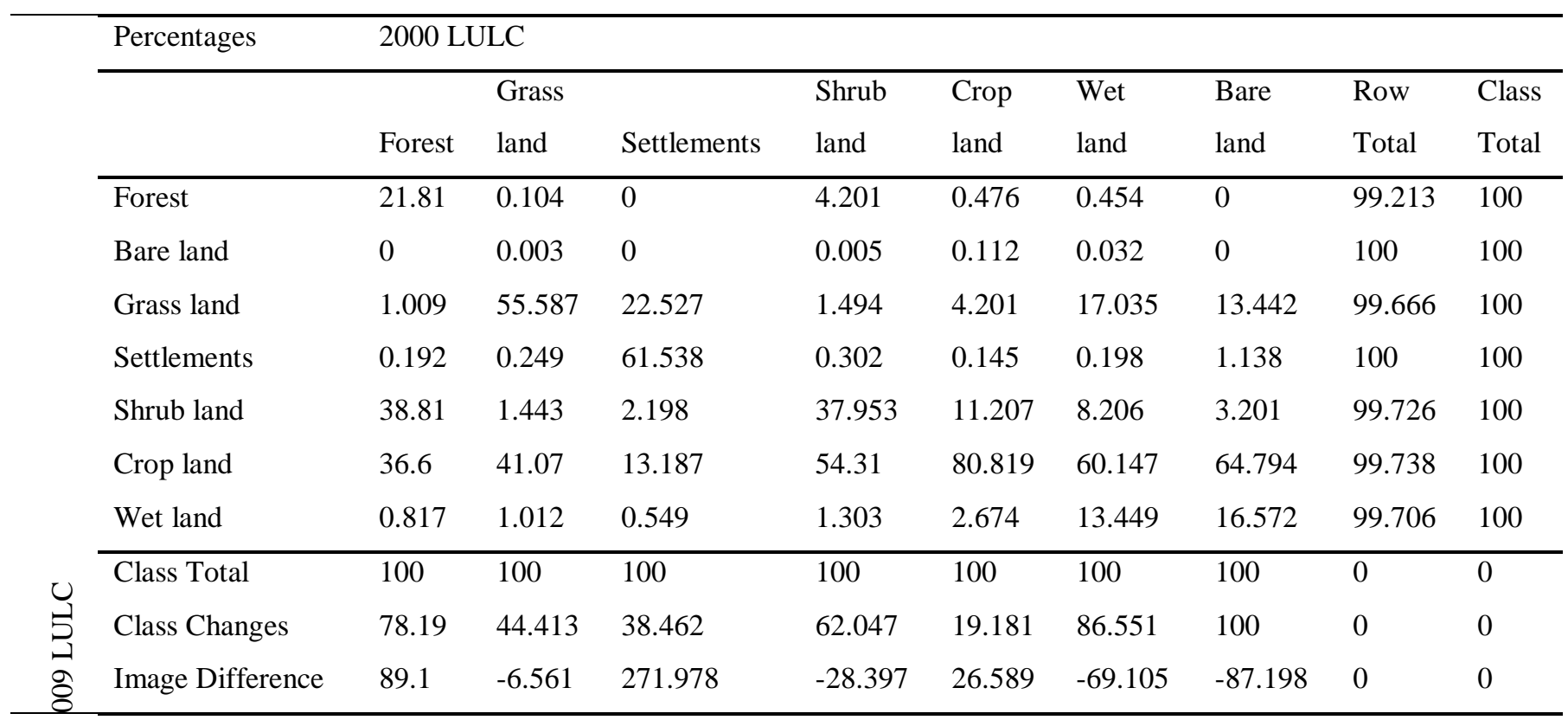


Himalayan J. Soc. Sci. \& Humanities ISSN: 0975-9891

Vol. 16, (2021) 13-33

DOI: https://doi.org/10.51220/hjssh.v16i1.2

Table 3: Land use land cover changes of 2009 to 2018 in hectares

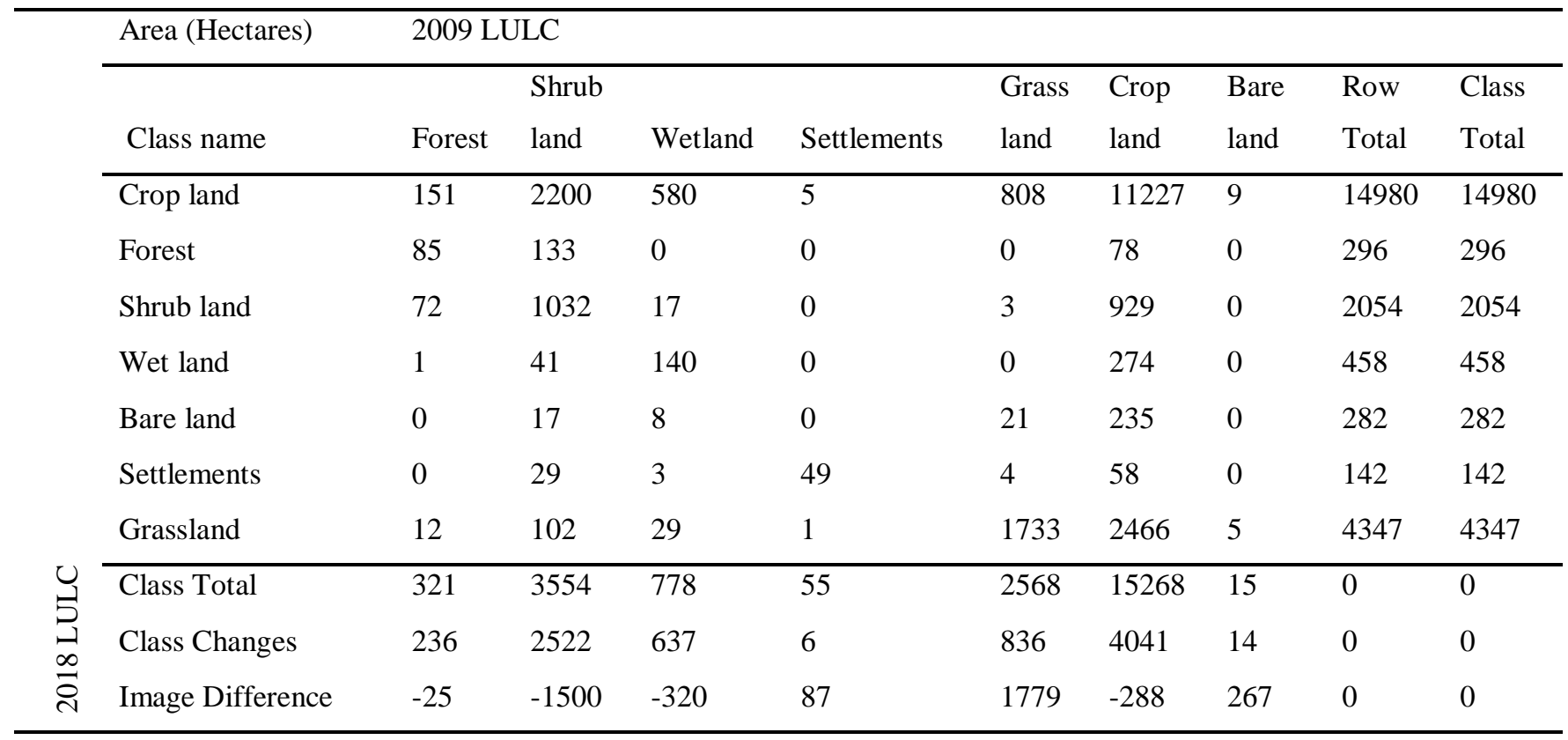

Table 4: Land use land cove changes of 2009 to 2018 in percentages

\begin{tabular}{|c|c|c|c|c|c|c|c|c|c|c|}
\hline & \multirow{3}{*}{ Percentages } & \multicolumn{9}{|c|}{2009 LULC } \\
\hline & & & Shrub & Wet & & Grass & Crop & & Row & Class \\
\hline & & Forest & land & land & Settlements & land & land & Bare land & Total & Total \\
\hline & Crop land & 46.945 & 61.9 & 74.627 & 9.329 & 31.451 & 73.532 & 61.963 & 100 & 100 \\
\hline & Forest & 26.485 & 3.743 & 0.023 & 0 & 0 & 0.51 & 0 & 100 & 100 \\
\hline & Shrub land & 22.534 & 29.037 & 2.198 & 0 & 0.13 & 6.087 & 0 & 100 & 100 \\
\hline & Wet land & 0.42 & 1.162 & 18.061 & 0.164 & 0 & 1.797 & 0 & 100 & 100 \\
\hline & Bare land & 0 & 0.468 & 1.064 & 0 & 0.817 & 1.541 & 2.454 & 100 & 100 \\
\hline & Settlements & 0.028 & 0.826 & 0.336 & 88.871 & 0.137 & 0.38 & 0 & 100 & 100 \\
\hline & Grass land & 3.587 & 2.864 & 3.691 & 1.637 & 67.466 & 16.153 & 35.583 & 100 & 100 \\
\hline \multirow{3}{*}{$\begin{array}{l}U_{S} \\
\text { S. } \\
\infty \\
0 \\
0\end{array}$} & Class Total & 100 & 100 & 100 & 100 & 100 & 100 & 100 & 0 & 0 \\
\hline & Class Changes & 73.515 & 70.963 & 81.939 & 11.129 & 32.534 & 26.468 & 97.546 & 0 & 0 \\
\hline & Image Difference & -7.791 & -42.202 & -41.178 & 159.083 & 69.26 & -1.885 & 1819.018 & 0 & 0 \\
\hline
\end{tabular}


Himalayan J. Soc. Sci. \& Humanities ISSN: 0975-9891

Vol. 16, (2021) 13-33

DOI: https://doi.org/10.51220/hjssh.v16i1.2

Table 5: Land use land cover changes of 2000 to 2018 in hectares

\begin{tabular}{|c|c|c|c|c|c|c|c|c|c|c|}
\hline & \multirow[t]{3}{*}{ Area (in hectare) } & \multicolumn{9}{|c|}{2000 LULC } \\
\hline & & & Shrub & Wet & Bare & & Grass & Crop & Row & Class \\
\hline & & Forest & land & land & land & Settlements & land & land & Total & Total \\
\hline & Crop land & 94 & 3169 & 1683 & 88 & 4 & 1104 & 8776 & 14919 & 14958 \\
\hline & Forest & 25 & 199 & 16 & 0 & 0 & 3 & 50 & 292 & 294 \\
\hline & Shrub land & 34 & 1057 & 199 & 3 & 0 & 22 & 737 & 2052 & 2058 \\
\hline & Wet land & 2 & 153 & 151 & 2 & 0 & 2 & 146 & 454 & 456 \\
\hline & Bare land & 0 & 18 & 15 & 4 & 0 & 10 & 234 & 280 & 281 \\
\hline & Settlements & 0 & 42 & 15 & 2 & 9 & 13 & 61 & 143 & 143 \\
\hline \multirow{4}{*}{ 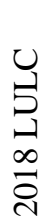 } & Grass land & 13 & 315 & 415 & 14 & 2 & 1568 & 1988 & 4315 & 4328 \\
\hline & Class Total & 169 & 4973 & 2505 & 114 & 15 & 2736 & 12037 & 0 & 0 \\
\hline & Class Changes & 144 & 3916 & 2355 & 111 & 6 & 1168 & 3261 & 0 & 0 \\
\hline & Image Difference & 124 & & -2049 & 167 & 128 & 1592 & 2922 & 0 & 0 \\
\hline
\end{tabular}

Table 6: Land use land cover changes of 2000 to 2018 in percentages

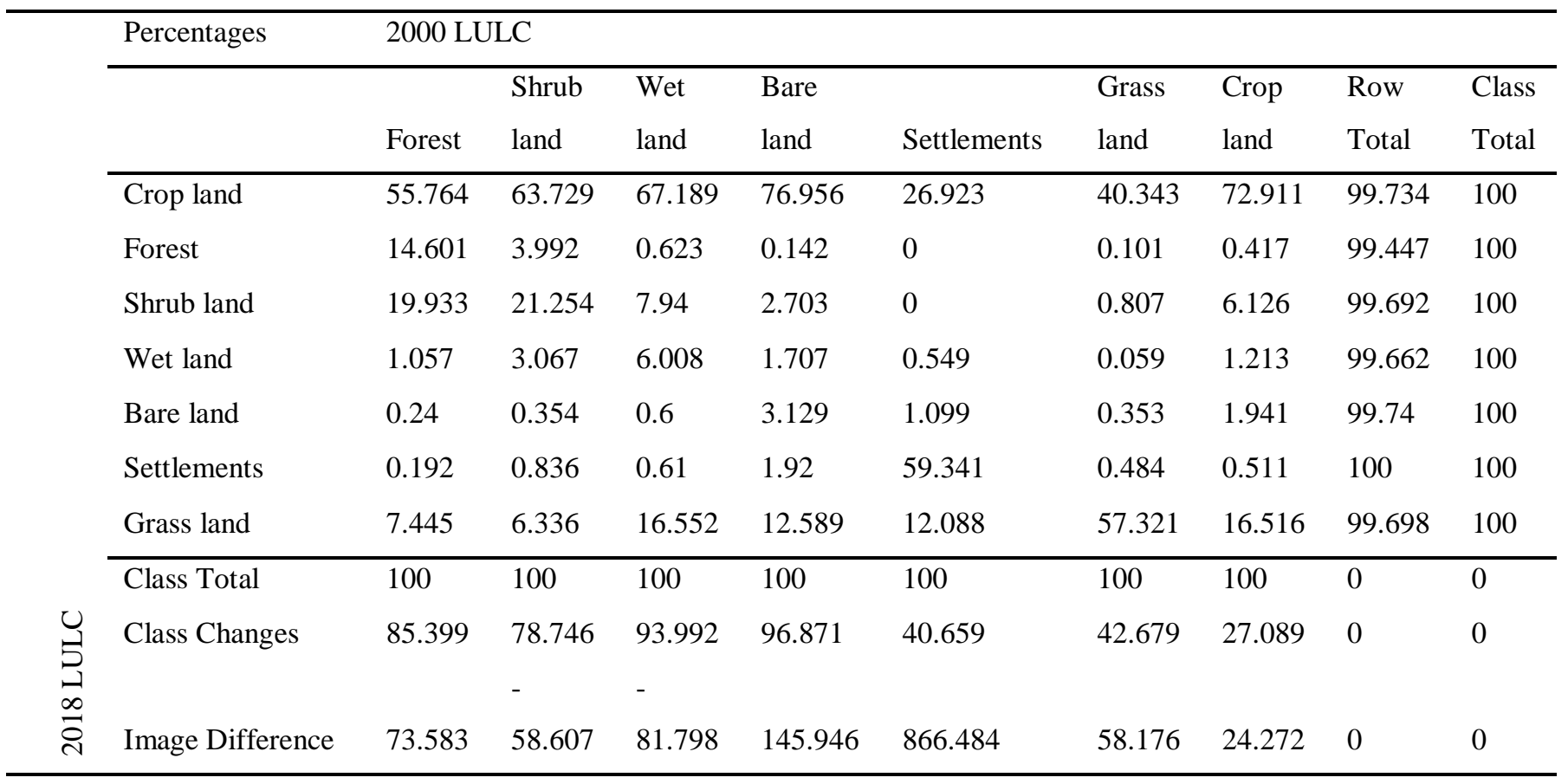


Himalayan J. Soc. Sci. \& Humanities ISSN: 0975-9891

Vol. 16, (2021) 13-33

DOI: https://doi.org/10.51220/hjssh.v16i1.2

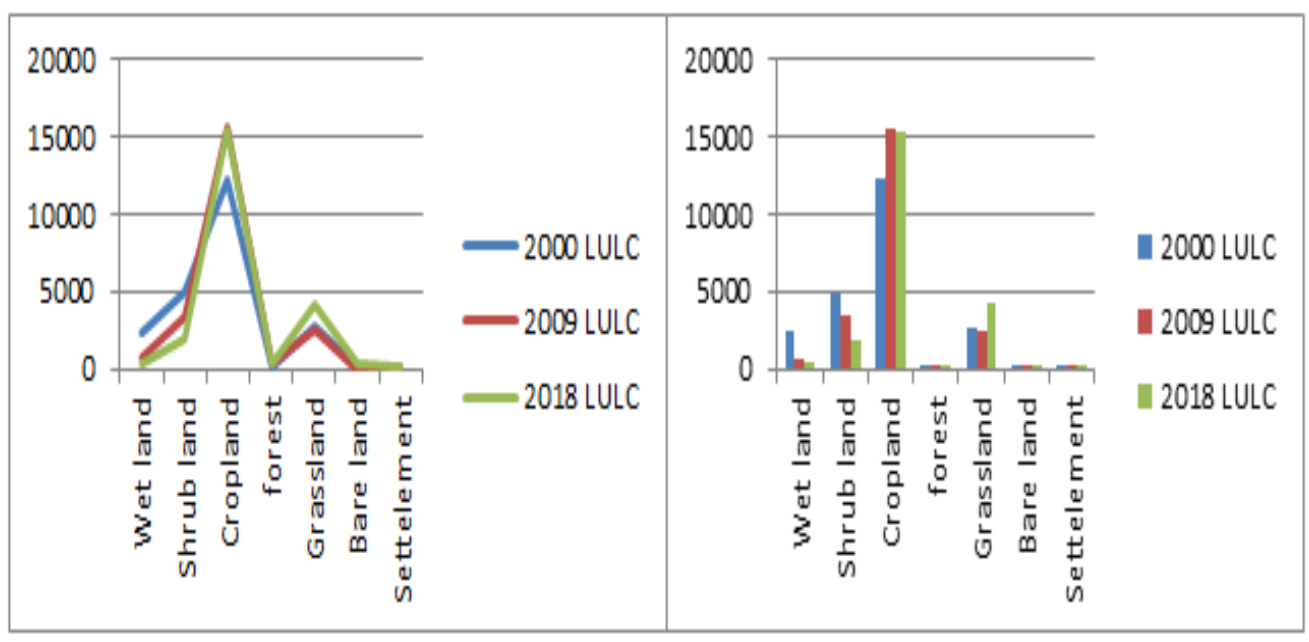

Figure 2: Land use land cover changes in 2000, 2009, and 2018

\section{Result of accuracy analysis}

Classification accuracy could be affected by lack of high resolution of images used and lack of previous knowledge of the area, always error expected consequently. To assess the classification accuracy, confusion matrix was used. Confusion matrix indicates the nature of the classification error. As it is shown (Table 7) for 2000 the overall accuracy and kappa coefficient is $88.37 \%$ and 0.8238 respectively. This shows $88.37 \%$ of the land use and land cover classes are correctly classified. Based on assessment made, producer accuracy of crop land/agricultural land was found to be $88.51 \%$ and user accuracy is found to be $89.53 \%$ respectively that is in agreement with study of (Kaul and Sopan 2016, Srivastava et.al.2012)

Table 7: Analysis result producers and users Accuracy of 2000

\begin{tabular}{|c|c|c|c|c|c|c|}
\hline & & & Classified & Number & Producers & Users \\
\hline $\mathrm{S} / \mathrm{N}$ & Class name & Reference Totals & Totals & Correct & Accuracy & Accuracy \\
\hline 1 & Bare land & 0 & 0 & 0 & --- & --- \\
\hline 2 & Forest & 1 & 1 & 1 & $100.00 \%$ & $100.00 \%$ \\
\hline 3 & Shrub land & 42 & 40 & 37 & $88.10 \%$ & $92.50 \%$ \\
\hline 4 & Crop land & 87 & 86 & 77 & $88.51 \%$ & $89.53 \%$ \\
\hline 5 & Wet land & 24 & 22 & 20 & $83.33 \%$ & $90.91 \%$ \\
\hline 6 & Grass land & 17 & 22 & 16 & $94.12 \%$ & $72.73 \%$ \\
\hline 7 & Settlements & 1 & 1 & 1 & $100.00 \%$ & $100.00 \%$ \\
\hline
\end{tabular}


Himalayan J. Soc. Sci. \& Humanities ISSN: 0975-9891

Vol. 16, (2021) 13-33

DOI: https://doi.org/10.51220/hjssh.v16i1.2

In the (Table 8) Accuracy assessment report of 2009 classification based on assessment made, producer accuracy of crop land/agricultural land is found to be $96.72 \%$ and user accuracy was found to be $88.06 \%$. Generally, overall classification accuracy is $86.87 \%$ and kappa coefficient found to be 0.8546 . This shows that land use land cover classes were almost correctly classified. In the same way, accuracy assessment of 2018 (Table 9) shows that user accuracy of crop land/agricultural land was $87.88 \%$ and producer accuracy was found to be $93.55 \%$. Over all accuracy of the classification was $85.86 \%$ and kappa coefficient was 0.8335 which is more or less similar to the findings of Kaul and Sopan 2016, Fahad et 2020).

Table 8: Analysis result of producers and users accuracy of 2009

\begin{tabular}{|c|c|c|c|c|c|c|}
\hline \multirow[t]{2}{*}{$\mathrm{S} / \mathrm{N}$} & & Reference & Classified & Number & Producers & Users \\
\hline & Class Name & Totals & Totals & Correct & Accuracy & Accuracy \\
\hline 1 & Forest & 1 & 1 & 1 & $100.00 \%$ & $100.00 \%$ \\
\hline 2 & Bare land & 0 & 0 & 0 & --- & --- \\
\hline 3 & Grass land & 15 & 11 & 9 & $60.00 \%$ & $81.82 \%$ \\
\hline 4 & Settlements & 0 & 0 & 0 & --- & --- \\
\hline 5 & Shrub land & 18 & 16 & 14 & $77.78 \%$ & $87.50 \%$ \\
\hline 6 & Crop land & 61 & 67 & 59 & $96.72 \%$ & $88.06 \%$ \\
\hline 7 & Wet land & 4 & 4 & 3 & $75.00 \%$ & $75.00 \%$ \\
\hline
\end{tabular}

Table 9: Analysis result of producers and users accuracy of 2018

\begin{tabular}{|c|c|c|c|c|c|c|}
\hline & & Reference & Classified & Number & Producers & Users \\
\hline $\mathrm{S} / \mathrm{N}$ & Class Name & Totals & Totals & Correct & Accuracy & Accuracy \\
\hline 1 & Crop land & 62 & 66 & 58 & $93.55 \%$ & $87.88 \%$ \\
\hline 2 & Forest & 1 & 1 & 1 & $100.00 \%$ & $100.00 \%$ \\
\hline 3 & Shrub land & 9 & 9 & 7 & $77.78 \%$ & $77.78 \%$ \\
\hline 4 & Wet land & 3 & 2 & 2 & $66.67 \%$ & $100.00 \%$ \\
\hline 5 & Bare land & 1 & 1 & 1 & $100.00 \%$ & $100.00 \%$ \\
\hline 6 & Settlements & 1 & 1 & 1 & $100.00 \%$ & $100.00 \%$ \\
\hline 7 & Grass land & 22 & 19 & 15 & $68.18 \%$ & $78.95 \%$ \\
\hline
\end{tabular}


Himalayan J. Soc. Sci. \& Humanities ISSN: 0975-9891

Vol. 16, (2021) 13-33

DOI: https://doi.org/10.51220/hjssh.v16i1.2

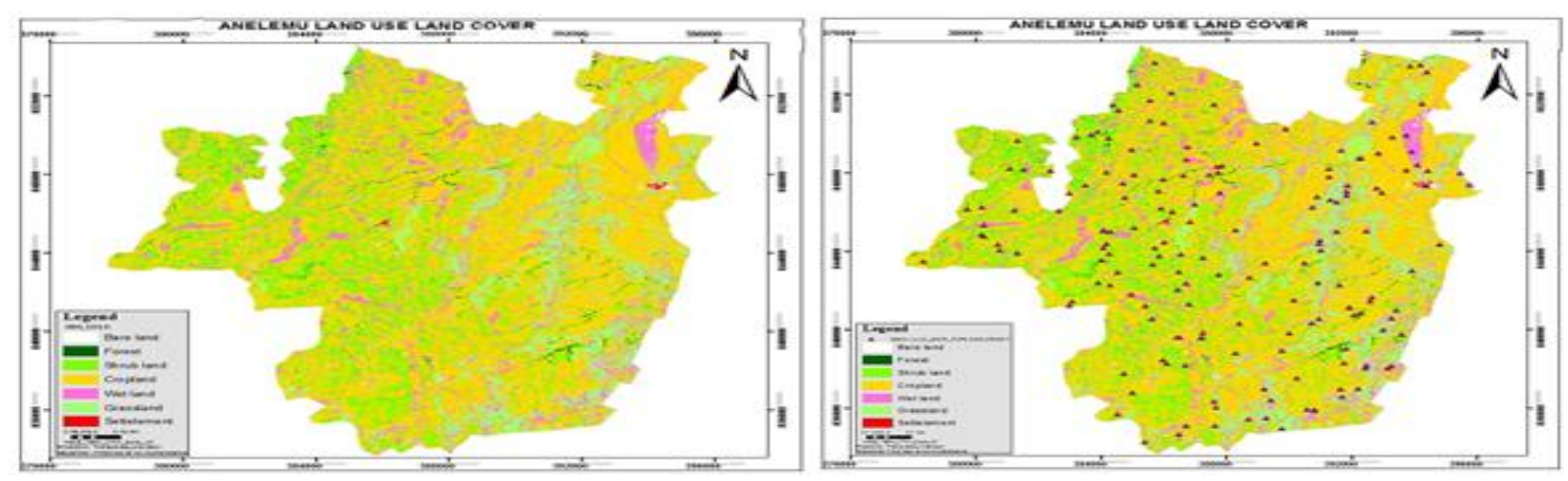

Figure 3: Land use land cover changes and accuracy and analysis of 2000

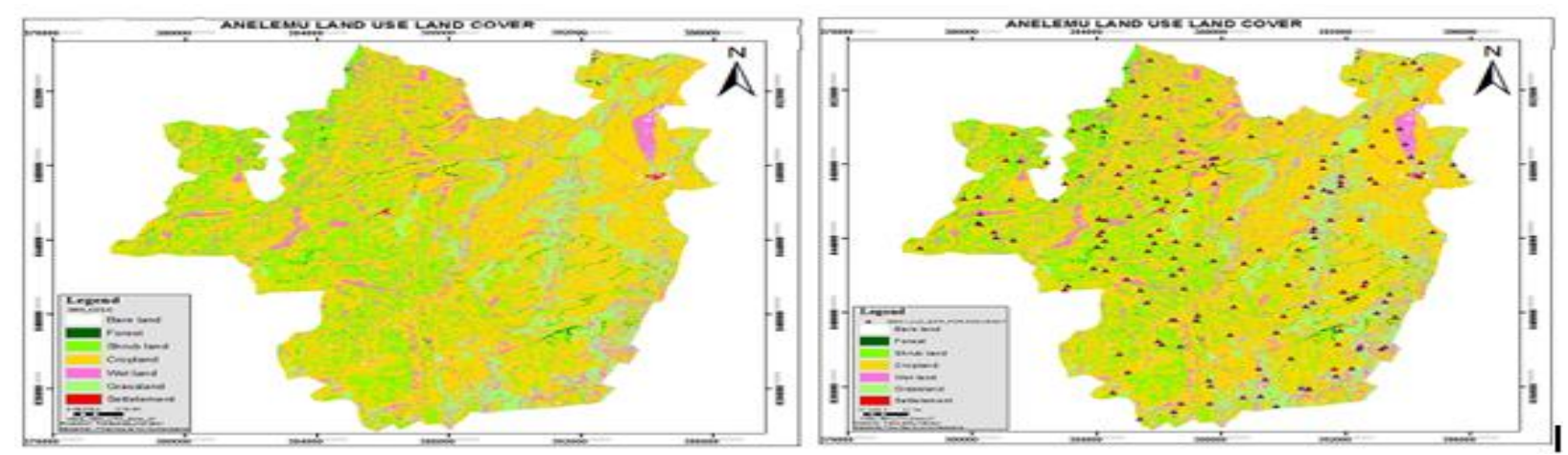

Figure 4: Land use land cover changes and accuracy analysis result of 2009

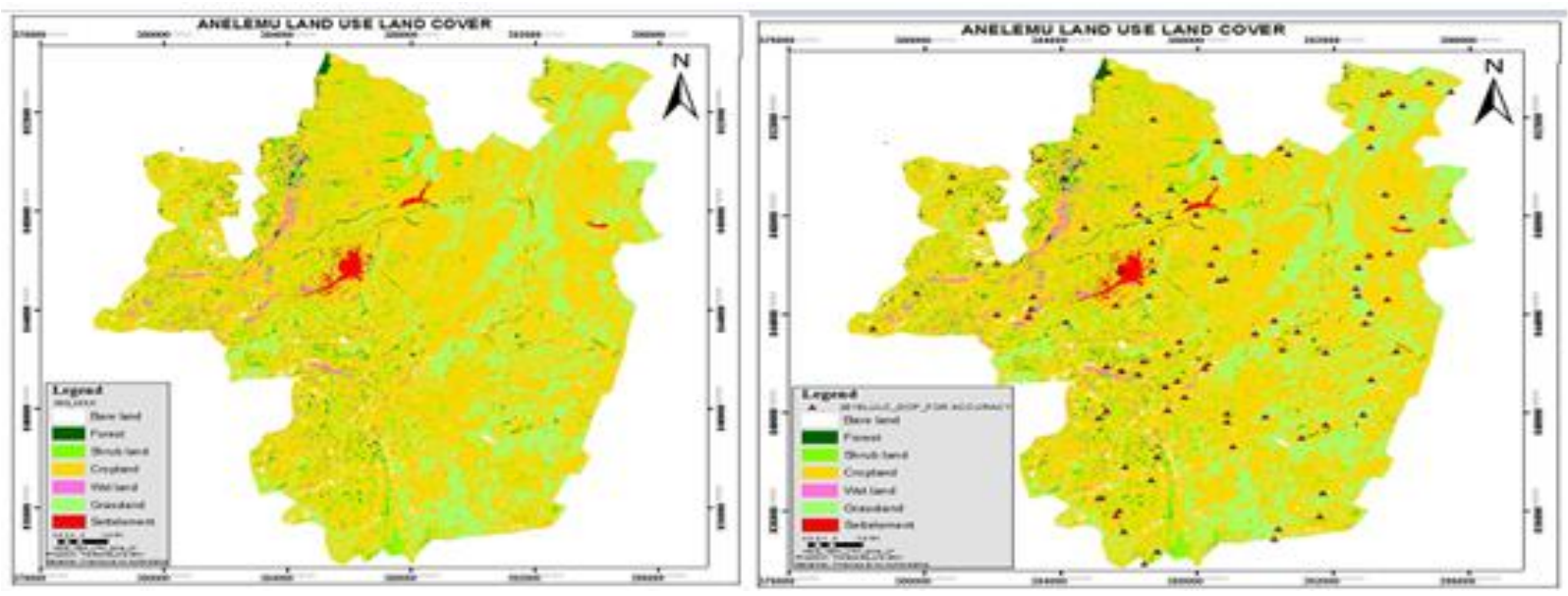

Figure 5: Land use land cover changes and accuracy analysis result of 2018 
Himalayan J. Soc. Sci. \& Humanities ISSN: 0975-9891

Vol. 16, (2021) 13-33

DOI: https://doi.org/10.51220/hjssh.v16i1.2

\section{Socio-economic Analysis}

Characteristics of Households: Majority of the households 102 (85.8\%) were farmers and the remaining $17(14.3 \%)$ were doing small trade in addition to farm activities. all of the respondents households 112(94.1\%) were married. Widowed and divorced households constituted less than 7(5.9\%). The educational status of households involved in the survey indicated that $76(63.9 \%), 10(8.4 \%)$ and $10(8.4 \%)$ were at elementary, primary and secondary education respectively (Table 10). Regarding land owned by household, 98(82.4\%) were less than 1 hectares, 15(12.6\%) were 1-2 hectares and 6(5\%) of the respondents land size was greater than two hectares. Concerning means of land acquisition majority of the respondents about $89(74.8 \%$ ) owned by inherited and 30(25.2\%) was owned through reallocation of land (Table 10).

Table 10: Households characteristics

\begin{tabular}{lllll}
\hline No. & Characteristics & Specifications & Frequency & Percentage \\
\hline 1 & Respondents age in years & $25-35$ & 10 & 8.4 \\
& & $36-45$ & 38 & 31.9 \\
& & $>45$ & 71 & 59.7 \\
\hline 2 & Households size in number & $<4$ & 15 & 12.7 \\
& & 4 to 7 & 67 & 56.3 \\
& & $>7$ & 37 & 31 \\
\hline 3 & Respondents occupation & Farmer & 102 & 85.7 \\
& & off-farm & 17 & 14.3 \\
\hline 4 & Size of land holding & $<1$ ha & 98 & 82.4 \\
& & 1 to 2 ha & 15 & 12.6 \\
& & $>2$ ha & 6 & 5.0 \\
\hline 5 & Educational status & Elementary (1-4) & 76 & 63.9 \\
& & Primary (5-8) & 10 & 8.4 \\
& & Secondary (9-12) & 8 & 6.7
\end{tabular}

(Source: Field survey)

Besides general characteristics of the study focuses, years of experience of households living in the District were more than 25 years and above in the study area. Majority about $98.3 \%$ responded that land use land cover change is a problem in their locality. From respondents $47.9 \%$ the main cause of land cover land use change was over cultivation, $11 \%$ illegal cutting of tree, $32.1 \%$ need of crop land and $9 \%$ over grazing. This comes from different reasons. Among them mostly $100 \%$ believed due to soil 
Himalayan J. Soc. Sci. \& Humanities ISSN: 0975-9891

Vol. 16, (2021) 13-33

DOI: https://doi.org/10.51220/hjssh.v16i1.2

degradation followed by $85.7 \%$ it is due to soil fertility decline. According to remote sensing data in the (Table 1, 2, 3, 4, 5 and 6) confirms this idea which similar concept to the study of Islam et al 2002).

The crop land/agricultural land of Anlemo District accounts 36.6\% in 2000. In the year 2009 forest and shrub land coverage of the District surprisingly decreased. In the year 2018 the total coverage of crop land/agricultural land also increased to $55.76 \%$ of the total area of the District. This indicates that the main cause of land use land cover change in the study area was vegetation removal. Generally, remote sensing data and socio-economic data of the study area were indicated land use land cover change is a challenging problem in the District and the main cases for the changes were over cultivation, settlement, illegal cutting of forest for different purposes and over grazing were driving factors for land use and land cover change in the study area.

\section{Main Causes of Land Use and Land Cover Change in the Study Area}

Causes are the direct pressures exerted on land resources. The driving forces in the study area include population pressure, demand for agricultural land, over cultivation, resettlement, increased demands for forest products such fire wood and charcoal, less soil and water conservation practices, overgrazing, deforestation, declining crop productivity and agricultural encroachment in to marginal areas which is similar to the study report by Betru et al (2019). Fast population growth and the consequent high pressure on resources are expected to have an adverse effect on the existing natural resources of the area. Such rapid population growth in the area has already exerted pressure on the existing land resources through increasing the demand for food, wood for fuel and construction purposes, and other necessities. The expansion of agricultural lands toward forest and marginal lands, including continuous and over cultivation, has resulted in deforestation and soil degradation which is similar to that of Perović et al (2018) and Gashaw et al (2014).. Similarly, increased demands for fuel wood in the absence of alternative sources of energy have led to the destruction of forests.

According to socio-economic survey and key informant interview responses the major causes for land use land cover change in the District indicated that over cultivation $47.9 \%$, illegal cutting of trees $11 \%$, need of crop land $32.1 \%$ and over grazing accounts $9 \%$. Fuel wood have been the most important energy sources in rural Ethiopia in general and in the Anlemo District in particular; 83(69.8\%) of the respondents confirmed that fuel wood was most important, while 26(21.8\%) confirmed that charcoal was most important for cooking and heating. A few respondents $10(8.4 \%)$ told that they used crop residues as energy sources the idea is in harmony with the study of Melese (2016). 
Himalayan J. Soc. Sci. \& Humanities ISSN: 0975-9891

Vol. 16, (2021) 13-33

DOI: https://doi.org/10.51220/hjssh.v16i1.2

\section{Effect of Land Use and Land Cover Change on Agricultural Productivity}

Crop Productivity : Land use and land cover changes degrade the land's capacity for sustained use and regaining its natural cover. Specifically, changes in land use and land cover have a significant influence on soil resources and biodiversity. Its cumulative change has impact on reducing agricultural productivity. The major crop types grown in the study area were wheat, "teff" and maize. According to Anlemo District agricultural office and sampled households Wheat is the dominant crop in the District and more than 89(74.8\%) of respondent produce wheat, $60(71.4 \%)$ of respondents produce "teff", 42(35.3\%) produce maize and minor crops like fava-bean and peas are not in considerable amount which is with the same perception to that of Tefera (2011).

Regarding crop productivity in the study area before 20 years, households obtained from one hectare of (Table 12):

- Wheat was 34(28.6\%) respondents got 15-25 quintals and 45(37.8\%) respondents got 26-35 quintals and 40(33.6\%) respondents got greater than 35 quintals before 20 years, 28(23.5\%) respondents got 15-25 quintals, 56(47.1\%) respondents got 26-35 quintals and 35(29.4\%) respondents got greater than 35 quintals before 10 years and currently 37(31.1\%) respondents got 15-25 quintals, 67(56.3\%) respondents got 26-35 quintals and 15(12.6\%) respondents got greater than 35 quintals

- "Teff" was 32(26.9\%) respondents got 6-10 quintals and 87(73.1\%) respondents got 11-15 quintals before 20 years, 52(43.7\%) respondents got 6-10 quintals and 67(56.3\%) respondents got 11-15 quintals before 10 years and currently 74(62.2\%) respondents got 6-10 quintals and $45(37.8 \%)$ respondents got 11-15 quintals

- Maize was 51(42.9\%) respondents got 15-25 quintals and 68(57.1\%) respondents got 26-35 quintals before 20 years, 66(55.5\%) respondents got 15-25 quintals and 53(44.5\%) respondents got 26-35 quintals before 10 years and currently 78(65.5\%) respondents got 15-25 quintals and $41(34.5 \%)$ respondents got $26-35$ quintals

From the result, it is possible to understand the decline of agricultural productivity per individual household though the results of remote sensing data on land use change showed an increasing trend of agricultural land in the study District. The total agricultural land was increased in the past 30 years, but the agricultural productivity per unit area was decreased which is in harmony to study of Amenu et al (2017).

The major causes for crop yield reduction in the study area as perceived by respondents were soil degradation 119(100\%), climate change 102(85.7\%) and small farmland size 50(42\%) as it has been 
Himalayan J. Soc. Sci. \& Humanities ISSN: 0975-9891

Vol. 16, (2021) 13-33

DOI: https://doi.org/10.51220/hjssh.v16i1.2

indicated in the (Table 13). From this it is possible to realize that the degradation of agricultural land was accountable for the reduction of crop yield in the study area which is in agreement with study of Amenu et.al (2017) and Wyman and Stein (2010). They also reported high variability of rainy season recently as compared to before two decades ago. In addition, the data obtained from Ethiopia Meteorological Agency of Hawassa branch office indicated that the mean annual temperature of the study area was increased from $16.49^{\circ} \mathrm{c}$ in the year 2000 to $17.6^{\circ} \mathrm{c}$ in the year 2018. In the same way, mean annual rain fall of the District was erratic or changing from year to year which is similar to study report by Guzha et al. (2018). Thus, these climate changes also contributed to less agricultural productivity since the farming system of the study area is greatly reliant on rain-fed agriculture.

Moreover, key informants and survey respondents reported that the sedentary agricultural practice dominated since 2000, led to over cultivation of the land which has resulted in declining of soil fertility and a drop in agricultural productivity that is in agreement with study of Tadesse et al (2017). From all these, it is possible to confirm that the decline of agricultural productivity is due to change in land use and land cover. Regarding the production and productivity of major crops in the study area, (Table 11 and 12) indicated the responses of participant households which is almost similar to the study result of Mengistu et al (2012).

\section{Table 11: Households versus crop production}

\begin{tabular}{llll}
\hline S/N & Characteristics & Types of major crops grown & Frequency Vs percentage \\
\hline 1 & Most common & Wheat & $89(74.8 \%)$ \\
2 & Very common & "Teff" & $60(71.4 \%)$ \\
3 & Common & Maize & $42(35.3 \%)$ \\
\hline
\end{tabular}

*Owing to multiple responses percentages do not sum to 100 (Source: Field survey)

Table 12: Respondents versus percentages on crop productivity

\begin{tabular}{|c|c|c|c|c|}
\hline \multirow[t]{3}{*}{ Descriptions } & \multicolumn{2}{|c|}{ Before 20 Years } & Before 10 Years & \multirow[t]{2}{*}{ Current } \\
\hline & Respondents & Vs & Respondents & \\
\hline & Percentage & & Percentage & Respondents Vs Percentage \\
\hline \multicolumn{5}{|c|}{ Crop production per unit area } \\
\hline \multicolumn{5}{|l|}{ Wheat } \\
\hline 15.25 Quintals & $34(28.6 \%)$ & & $28(23.5 \%)$ & $37(31.1 \%)$ \\
\hline 26-35 Quintals & $45(37.8 \%)$ & & $56(47.1 \%)$ & $67(56.3 \%)$ \\
\hline > 35 Quintals & $40(33.6 \%)$ & & $35(29.4 \%)$ & $15(12.6 \%)$ \\
\hline
\end{tabular}


Himalayan J. Soc. Sci. \& Humanities ISSN: 0975-9891

Vol. 16, (2021) 13-33

DOI: https://doi.org/10.51220/hjssh.v16i1.2

\begin{tabular}{llll}
\hline Total & $119(100 \%)$ & $119(100 \%)$ & $119(100 \%)$ \\
\hline "Teff" & $32(26.9 \%)$ & $52(43.7 \%)$ & $74(62.2 \%)$ \\
\hline $\begin{array}{l}\text { 6-10 Quintals } \\
11-15 \text { Quintals }\end{array}$ & $87(73.1 \%)$ & $67(56.3 \%)$ & $45(37.8 \%)$ \\
$>15$ Quintals & & & \\
\hline Total & $119(100 \%)$ & $119(100 \%)$ & $119(100 \%)$ \\
\hline Maize & $51(42.9 \%)$ & $66(55.5 \%)$ & $78(65.5 \%)$ \\
\hline $15-25$ Quintals & $68(57.1 \%)$ & $53(44.5 \%)$ & $41(34.5 \%)$ \\
$26-35$ Quintals & & & $119(100 \%)$ \\
\hline 35 Quintals & $119(100 \%)$ & $119(100 \%)$ & \\
\hline
\end{tabular}

(Source: Field survey)

Table 13: Possible causes for crop yield reduction

\begin{tabular}{lll}
\hline S/N & Possible Causes & Respondents Vs. Percentage \\
\hline 1 & Soil Degradation & $119(100 \%)$ \\
2 & Land Fragmentation & $62(52.1 \%)$ \\
3 & Climate Change & $102(85.7 \%)$ \\
\hline
\end{tabular}

*Owing to multiple responses percentages do not sum to 100 (Source: Field survey)

\section{Livestock Productivity}

Anlemo District, as in most other parts of the country, livestock is an important part of the agricultural system in the area. As it can be seen from the (Table 14), the majority of respondents owned cow, accounted for 107(89.9\%), oxen 95(79.8\%), shoat for 116(97.5\%). Regarding the trend of the livestock in terms of their number and productivity over the past 20 years or from 2000 to 2018, about 104(87.4\%) of the respondents reported that livestock numbers and productivity had decreased in the area, while $15(12.6 \%)$ of the households reported an increase in numbers and productivity. The number and productivity of livestock of the households was decreasing from past to present which is similar to the study result of Mekasha et al (2014). The main reason for reduction of livestock number and productivity, about 93(78.2\%) of respondents indicated that the main reason for the decrease in productivity and numbers of livestock per households had been shortage of grazing land, 81(68.1\%) is due to lack of fodder and the remaining 54(45.4\%) is rated for diseases. Respondents indicated that the main reason behind the shortage of livestock feed was expansion of agricultural land towards grazing and forest land. According to interview with respondents the source of livestock feed were 14(11.8\%) open grazing, $107(89.9 \%$ ) control grazing (one's own possession) and crop residue accounts for 107(89.9\%). 
Himalayan J. Soc. Sci. \& Humanities ISSN: 0975-9891

Vol. 16, (2021) 13-33

DOI: https://doi.org/10.51220/hjssh.v16i1.2

As it has been stated by Weindl et al (2017) that the land use change data shows that, declining of forest and grazing land that affects the availability of feed resources for the livestock. According to the socioeconomic survey data obtained from key informant interview and households response, the trends of livestock number and productivity shows decreasing to the same as crop production from past to present. The reasons for the decreasing of livestock number and productivity were identified. The respondents recognized that grazing area had decreased due to expansion of agricultural land, decrease size and productivity of grazing land and expansion of cultivated land. Based on the study, 119(100\%) of interviewed households depend on agriculture (both crop production and livestock production) which is the same to study of Wirsenius et al (2010). However, results of the survey showed that the crop and livestock productivity were mainly due to removal of vegetation cover and increasing demand of agricultural land induced by human population pressure in the study area that is in agreement with Amsalu and Addisu (2014).

Table 14: Respondents versus livestock productivity

\begin{tabular}{|c|c|c|c|c|}
\hline & & & Respondents' & Vs \\
\hline $\mathrm{S} / \mathrm{N}$ & Descriptions & Characteristics & Percentage & \\
\hline \multirow[t]{3}{*}{1} & Quantity & Cow & $107(89.9 \%)$ & \\
\hline & & $\mathrm{Ox}$ & $95(79.8 \%)$ & \\
\hline & & Shoat & $116(97.5 \%)$ & \\
\hline \multicolumn{5}{|c|}{ Total $*$ Owing to multiple responses percentages do not sum to 100} \\
\hline \multirow[t]{2}{*}{2} & Trends in productivity & Increase & $15(12.6 \%)$ & \\
\hline & & Decrease & $104(87.4 \%)$ & \\
\hline \multicolumn{2}{|l|}{ Total } & & $119(100 \%)$ & \\
\hline \multirow[t]{3}{*}{3} & Reason for decreasing trend & Shortage of grazing land & $93(78.2 \%)$ & \\
\hline & & Lack of fodder & $81(68.1 \%)$ & \\
\hline & & Disease & $54(45.4 \%)$ & \\
\hline \multicolumn{5}{|c|}{ Total *Owing to multiple responses percentages do not sum to 100} \\
\hline \multirow[t]{3}{*}{4} & Sources of fodder & Open grazing & $14(11.8 \%)$ & \\
\hline & & Control grazing & $107(89.9 \%)$ & \\
\hline & & Crop residues & $107(89.9 \%)$ & \\
\hline
\end{tabular}

Total *Owing to multiple responses percentages do not sum to 100

(Source: Field survey) 


\section{Conclusion}

The study used an integrated approach to understand past and the present conditions of the study area by using satellite images provided necessary data for study area. Based on the findings, analysis of land use and land cover classification for the study periods shown that there is rapid increase in agricultural land and built up area, while there is a decreasing trend in forest cover.

Generally, the results also show that the extent of agricultural land and built up area has increased the whole periods at the expense of deforestation or forest cover change. The general trend observed was a decrease in forest cover. A corresponding increase was observed in agricultural land, built up areas. The decrease in forest cover particularly reflects the considerable expansion of agricultural land, resettlement and illegal cutting of trees in the area. In the study area, the vegetation cover was converted to cultivated land and built up area. As a result, land degradation occurs and productivity is decreasing; consequently, the current crop yield per unit area is gradually declined. Similarly, the number of livestock productivity per household also declined that may be due to the low availability of livestock feed. Land use and land cover changes also related with the livelihoods of the local population, i.e. socio-economic conditions and access to agricultural land and population growth. The area is one of densely populated areas of the country more than $87.3 \%$ of sampled house hold heads replied that their family size greater than four members per household and land use and land cover change may affect natural resources and reduce agricultural productivity on which the livelihood of the local community mainly relied on.

\section{Recommendations}

From the result obtained from satellite image and actual field observations made during the study, the following recommendations are forwarded:

- In the face of the growing household size, land shortage and growing number of landless youths, rather than agricultural activities the enhance vegetation or forest clearance, other fields of job like manufacturing and service provision and related activities should be created at the local level.

- In order to improve agricultural productivity the small landholding size of the area necessitated the intensification of agriculture through specialization and diversification with the use of special seeds, chemical and natural fertilizers are very important with continuous supporting of Development Agents (DAs) at the kebele level in order to improve agricultural productivity.

- Agriculture and rural development office of Anlemo District and other governmental and nongovernmental organizations should take their own share of responsibilities in solving the challenges related to crop productivity, livestock productivity and natural resources management. 
Himalayan J. Soc. Sci. \& Humanities ISSN: 0975-9891

Vol. 16, (2021) 13-33

DOI: https://doi.org/10.51220/hjssh.v16i1.2

- This research can help as an initial point. However, further research in the area is highly recommendable in order to demonstrate radical conversion of one land cover type to the other and to take conservation and rehabilitation action.

Therefore, the current trends in land use and land cover must be improved towards the resources management and conserving of the existing natural resources in the study area through community participation and using sustainable land resources management plan so that agricultural productivity can be improved.

\section{Acknowledgements}

We are grateful to the farmers Anlemo District who shared us their immense knowledge and their experience by devoting their valuable time and lesson learnt from them. We would also like to thanks staff of Anlemo District office of agriculture and natural resources for their unreserved cooperation during this study. Last, but not least, we are indebted to Wachemo University for the fund raised.

\section{REFERENCES}

Abate, A. and Lemenih, M. (2014). Detecting and quantifying land use/land cover dynamics in Nadda Asendabo Watershed, South Western Ethiopia. International Journal of Environmental Sciences, 3(1), pp.45-50.

Alemu, B. (2015). The effect of land use land cover change on land degradation in the highlands of Ethiopia. Journal of Environment and Earth Science, 5(1), pp.1-13.

Amenu, B.T., Mathewos, M. and Seid, G. (2017). Analysis of Land Cover Change of Dedo District, Jimma Zone, Oromia Regional Government, South Western Ethiopia.

Amsalu, T. and Addisu, S. (2014). Assessment of grazing land and livestock feed balance in GummaraRib Watershed, Ethiopia. Current Agriculture Research, 2(2).

Baude, M., Meyer, B.C. and Schindewolf, M. (2019). Land use change in an agricultural landscape causing degradation of soil based ecosystem services. Science of the Total Environment, 659, pp.1526-1536.

Betru, T., Tolera, M., Sahle, K. and Kassa, H. (2019). Trends and drivers of land use/land cover change in Western Ethiopia. Applied Geography, 104, pp.83-93.

Ejigu, D. (2016). Application of Remote Sensing and Geographic Information System in Ecology.

Fahad, K.H., Hussein, S. and Dibs, H. (2020). January. Spatial-Temporal Analysis of Land Use and Land Cover Change Detection Using Remote Sensing and GIS Techniques. In IOP Conference Series: Materials Science and Engineering (Vol. 671, No. 1, p. 012046). IOP Publishing.

Firdaus, R., Nakagoshi, N., Idris, A. and Raharjo, B. (2014). The relationship between land use/land cover change and land degradation of a natural protected area in Batang Merao Watershed, Indonesia. In Designing Low Carbon Societies in Landscapes (pp. 239-251). Springer, Tokyo.

Gashaw, T., Bantider, A. and Mahari, A. (2014). Evaluations of land use/land cover changes and land degradation in Dera District, Ethiopia: GIS and remote sensing based analysis. International Journal of Scientific Research in Environmental Sciences, 2(6), p.199.

Gessesse, B., Bewket, W. and Bräuning, A. (2015). Model-based characterization and monitoring of runoff and soil erosion in response to land use/land cover changes in the Modjo watershed, Ethiopia. Land degradation \& development, 26(7), pp.711-724. 
Himalayan J. Soc. Sci. \& Humanities ISSN: 0975-9891

Vol. 16, (2021) 13-33

DOI: https://doi.org/10.51220/hjssh.v16i1.2

Guzha, A.C., Rufino, M.C., Okoth, S., Jacobs, S. and Nóbrega, R.L.B. (2018). Impacts of land use and land cover change on surface runoff, discharge and low flows: Evidence from East Africa. Journal of Hydrology: Regional Studies, 15, pp.49-67.

Islam, K., Jashimuddin, M., Nath, B. and Nath, T.K. (2002). Land use classification and change detection by using multi-temporal remotely sensed imagery: The case of Chunati wildlife sanctuary, Bangladesh. The Egyptian Journal of Remote Sensing and Space Science, 21(1), pp.37-47.

KAHSAY, H. (2018). The Effects of Population Growth on Land Use and Land Cover Changes in Ganta Afeshum District, Eastern Tigray Zone, Ethiopia during 2000 to 2014.

Kaul, H.A. and Sopan, I. (2012). Land use land cover classification and change detection using high resolution temporal satellite data. J. Environ, 1(4), pp.146-152.

Kidane, Y., Stahlmann, R. and Beierkuhnlein, C. (2012). Vegetation dynamics, and land use and land cover change in the Bale Mountains, Ethiopia. Environmental monitoring and assessment, 184(12), pp.7473-7489.

Kindu, M., Schneider, T., Teketay, D. and Knoke, T. (2013). Land use/land cover change analysis using object-based classification approach in Munessa-Shashemene landscape of the Ethiopian highlands. Remote Sensing, 5(5), pp.2411-2435.

Mekasha, A., Gerard, B., Tesfaye, K., Nigatu, L. and Duncan, A.J. (2014). Inter-connection between land use/land cover change and herders'/farmers' livestock feed resource management strategies: a case study from three Ethiopian eco-environments. Agriculture, ecosystems \& environment, 188, pp.150-162.

Melese, S.M. (2016). Effect of land use land cover changes on the forest resources of Ethiopia. International Journal of Natural Resource Ecology and Management, 1(2), p.51.

Mengistu, D.A., Waktola, D.K. and Woldetsadik, M. (2012). Detection and analysis of land-use and landcover changes in the Midwest escarpment of the Ethiopian Rift Valley. Journal of Land Use Science, 7(3), pp.239-260.

Mussa, M., Teka, H. and Mesfin, Y. (2017). Land use/cover change analysis and local community perception towards land cover change in the lowland of Bale rangelands, Southeast Ethiopia. International Journal of Biodiversity and Conservation, 9(12), pp.363-372.

Perović, V., Jakšić, D., Jaramaz, D., Koković, N., Čakmak, D., Mitrović, M. and Pavlović, P. (2018). Spatio-temporal analysis of land use/land cover change and its effects on soil erosion (Case study in the Oplenac wine-producing area, Serbia). Environmental monitoring and assessment, 190(11), p.675.

Sewnet, A. (2016). Land use/cover change at Infraz watershed by using GIS and remote sensing techniques, northwestern Ethiopia. International Journal of River Basin Management, 14(2), pp.133-142

Shiferaw, A. and Singh, K.L., (2011). Evaluating the land use and land cover dynamics in Borena Woreda South Wollo Highlands, Ethiopia. Ethiopian Journal of Business and Economics (The), 2(1).

Srivastava, P.K., Han, D., Rico-Ramirez, M.A., Bray, M. and Islam, T. (2012). Selection of classification techniques for land use/land cover change investigation. Advances in Space Research, 50(9), pp.1250-1265.

Tadesse, L., Suryabhagavan, K.V., Sridhar, G. and Legesse, G. (2017). Land use and land cover changes and Soil erosion in Yezat Watershed, North Western Ethiopia. International soil and water conservation research, 5(2), pp.85-94.

Tefera, M.M. (2011). Land-use/land-cover dynamics in Nonno district, central Ethiopia. Journal of Sustainable development in Africa, 13(1), pp.123-141. 
Weindl, I., Popp, A., Bodirsky, B.L., Rolinski, S., Lotze-Campen, H., Biewald, A., Humpenöder, F., Dietrich, J.P. and Stevanović, M. (2017). Livestock and human use of land: Productivity trends and dietary choices as drivers of future land and carbon dynamics. Global and Planetary Change, 159, pp.1-10.

Wessels, K.J., Van den Bergh, F., Roy, D.P., Salmon, B.P., Steenkamp, K.C., MacAlister, B., Swanepoel, D. and Jewitt, D. (2016). Rapid land cover map updates using change detection and robust random forest classifiers. Remote sensing, 8(11), p.888.

Wirsenius, S., Azar, C. and Berndes, G. (2010). How much land is needed for global food production under scenarios of dietary changes and livestock productivity increases in 2030?. Agricultural systems, 103(9), pp.621-638.

Wyman, M.S. and Stein, T.V.(2010). Modeling social and land-use/land-cover change data to assess drivers of smallholder deforestation in Belize. Applied Geography, 30(3), pp.329-342.

Yamane, T. (1967). Statistics: An Introductory analysis. 2nd Edition, Harper and Row, New York 